Gas(es):

Gases. M. C. Smith. 12,000 entries, by title, subject, and properties, with attached author list. Few before 1880 , since 1900 fairly covered. Brief abstracts and comments in some cases, tabulated data in some, a few critically covered, Everything of probable interest in connection with gas chemistry: physical properties, chemical reactions, manufacture, analysis, commercial application, etc. Conveniently arranged and indexed. For consultation, write Chemistry Section, Bureau of Stand ards, Washington, D. C.

Diffusion of gases through hot solids. B. Clifford Hendricks, 302 Chemistry Hall, University of Nebraska, Iincoln, Neb. 50 entries, by author title, and subject. 1863-1920. Abstracts included for practically all references. 75 per cent complete.

Gas absorption: machinery, process, theory: Edwin M. Baker, University of Michigan, Ann Arbor, Mich. Entries by author and subject. 1907-1919. Abstracts included for more important articles. Does not include patents; otherwise all articles listed in Chemical Abstracts

Preparation, chemical, and physical properties of gases. Gas Section Bureats of Standerds, Washington, D. C. 10,000 entries, by author and subject. 1800-date. Short abstracts included in a large number of cases. About complete.

Gelatin:

E. T. Oakes, 85 Ninth Ave., New York, N. Y. 350 entries, by author title, and subject. Up to date. Abstracts included.

See also Glue (Alexander), (Thiele).
Germanium:

Chemistry of germanium. Frank W. Douglas; Colorado College, Colorado Springs, Colo, Up to 1919.

Gilsonite:

See Petroleum (Carmichael).

Ginger:

Arthur D. Little, Inc., Cambridge, Mass, 20 entries, by author.

Glass:

Alexander Silverman, University of Pittsburgh, Pittsburgh, Pa. 6000 entries, by author and subject. 1822-1914. Practically complete. See also Sand (Richardson)

Glue:

Glue and gelatin. James Alexander, $255 \mathrm{~W}$. 108th St., New York, N. Y. To appear in an American ChEMrCaI, Societry monograph on this subject.

Glue and gelatin, including testing, chemical and physical methods, complete patent literature, and statistics. L. A. Thiele, Upper-Sandusky or Columbus, Ohio, 2000 entries, including 500 patents, by author and subject. 1814-1920. Abstracts included in part. Very nearly complete.

See also Casein (Snel1).

\title{
AMERICAN CONTEMPORARIES
}

\section{Ira Remsen}

$\mathrm{R}$

EMSEN is most widely known through his textbooks, which have reached every quarter of the globe and have been studied by tens of thousands of students from high school to university. He is best known to the initiated for the long list of researches he has carried out. He will be longest known for the journal which he founded and conducted for thirty-five years, and into which he gathered such a large proportion of American chemical research for that period. He is best loved and most revered by those who have attended his inimitable lectures and have come into close contact with his inspiring personality. More than any other man he typifies American chemistry, for the excellent reason that he has had such a large part in shaping American chemistry.

The founding of Johns Hopkins University in 1876, an institution of an entirely new kind, providing opportunities for advanced study and putting emphasis on research as had not been done before in America, gave a tremendous impetus to higher education. For Remsen it offered a wonderful opportunity, one for which he was peculiarly fitted by his type of mind, his training, his tastes, and his ambitions. He had learned the technic of research from such masters as Liebig, Wöhler, Volhard, and Fittig, but the research spirit he did not have to acquire, for it was that spirit which made him fare forth to a far country to seek the companionship of investigators.

Remsen came into American chemistry during its formative period when his leadership counted for most. Many who were later to mold chemical thought and practice were themselves molded by him. He taught a few hundred; they have taught many thousands. Comparatively few of his students went into commercial chemistry, but a number of these have been prom-

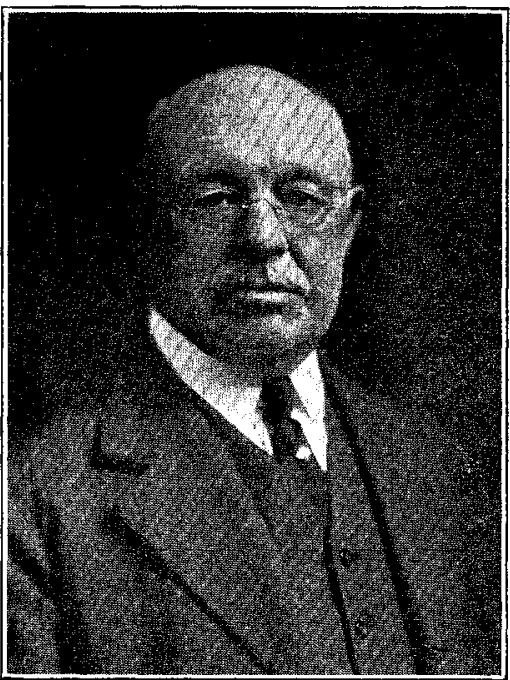

TRA REMSEN inent figures in some of our largest industries and have carried Remsen's ideals with them. He has never taken out a patent or turned his hand to commercialize any of his discoveries, and has always taught pure chemistry, yet few men have had so great an influence on applied chemistry.

The presidency of the university was thrust upon him to the detriment of chemistry and the violation of his own tastes, but it was desirable that the direction of the university fall into the hands of one who had shared in creating its ideals and who could be trusted to further them. His administration, 19011913, was a period of steady progress against difficulties, and was marked by the founding of the school of engineering and the removal of the university to its present splendid location near the edge of the city.

He has served his city, his state, and his country on various commissions, giving his time and strength freely for the public good.

The years since his retirement, in 1913 , he has spent in travel, in revising his books, and in giving advice, as requested, to the Government and to several large industries.

Remsen is more than a famous investigator, more than a writer of luminous texts, more than a discriminating editor, more than an inspiring teacher, and more than a university president; he is a real man, interested in life, loving the out-of-doors, full of kindly humor, quick to understand, accessible to all, helpful as a friend, sane in judgment, kindly in estimating others, and scrupulously honest and fair in all his dealings.

He has a way of thinking things through for himself and then going forward, and is not easily turned aside, but never needlessly antagonizes others. Chemists love to honor him and with good reason.

E. EMMET REID 